\title{
EPOXY RFSSINS - A DISCUSSION OF CURING SYSTEMS
}

Epoxy monomers, as such, are about as old as the automobile. In 1891, just a few years before the start of the Spanish-American War, a chemist by the name of Lindeman ${ }^{2}$ described the preparation of resinous materials of this type. The actual curing systems, however, which convert the liquid base resin to a mechanically strong solid, are quite new. Surprisingly enough, the basic patents covering the acid-anhydride and amine cures have been granted within the last fifteen years. In addition, numerous modification and improvement patents have been issued within the past five years.

Today, the epoxy casting resins represent a unique class of electrical insulating materials, and as such are of prime interest to the Sandia Corporation. This paper summarizes work which has been performed in our Materials Lahoratory in an attempt to correlate certain physical and electrical data with chemical structure.

The principal reaction which leads to the formation of the most important liquid epoxy resin is illustrated in Slide 1. By proper control of the alkaline concentration, and careful utilization of a large excess of epichiorohydrin, a liquid product will result. The more epichlorohydrin that is used, the shorter are the chains of the molecules, since epichlorohydrin acts as a chain stopper. The reaction can also be varied to produce the solid resins, wherein " $n$ " will have values greater than 1.5. This discussion, however, is concerned primar1ly with those liquid resins having an " $n$ " value of approximately 0.15 to 0.20 .

The problem of converting the liquid monomeric epoxy resin to a mechanically strong solid is the problem of curing the resin. This requires a chemical reaction which ties the resin molecules together into as large molecular units as are possible. Ideally, an entire casting should be composed of one super molecule.

Polymerization of epoxy resins may occur in an acidic or basic environment throigh catalysis, reactive coupling, or a combination of the two. In amine curing systems, the epoxy monomers may be linked together primarily through the terminal epoxy groups. An illustration of reactive coupling is shown in Slide 2, wherein 4 equivalents of epoxy are reacted with 4 equivalents of active hydrogen. Additional epoxy and amine will continue to react as in the above illustration until a highly cross-linked resin is formed. If the proportion of amine groups to epoxide is near equivalency, the resin will possess the superior electrical and physical properties characteristic of the given hardener.

In contrast to the reactive system which requires equivalent proportions of epoxy group and amino-hydrogen, there is the catalytic system. Catalytic cures are unique in that the rate of cure is much easier to control through proper choice of catalyst. With few exceptions, catalytic cures are not spontaneous, and for the most part require varying degrees of heat to bring about complete cross-linking. An example of a purely. catalytic curing system is shown on Slide 3. The electron-rich tertiary amine upon attacking the epoxide molecule, forms the fonic structure. 


\section{DISCLAIMER}

This report was prepared as an account of work sponsored by an agency of the United States Government. Neither the United States Government nor any agency Thereof, nor any of their employees, makes any warranty, express or implied, or assumes any legal liability or responsibility for the accuracy, completeness, or usefulness of any information, apparatus, product, or process disclosed, or represents that its use would not infringe privately owned rights. Reference herein to any specific commercial product, process, or service by trade name, trademark, manufacturer, or otherwise does not necessarily constitute or imply its endorsement, recommendation, or favoring by the United States Government or any agency thereof. The views and opinions of authors expressed herein do not necessarily state or reflect those of the United States Government or any agency thereof. 


\section{DISCLAIMER}

Portions of this document may be illegible in electronic image products. Images are produced from the best available original document. 
This serves to attack other epoxide molecules, continually propagating the same reaction, until the ends of the polymer molecules are completely joined together.

Catalytic amine cures for the most part produce castings having heat distortions in the range of $130^{\circ} \mathrm{F}$ and $220^{\circ} \mathrm{F}$. This seems to be due to the constant character of the resin structure, and the fact that the catalyst is not effectively integrated within the polymer, network. In direct contrast, the reactive amines produce a cured resin having physical properties greatly dependent on the structure of the amine itself; as 1llustrated in Slide 4. Cpd. (1) is observed to posses 4 active hydrogens on a long, flexible chain. This hardener therefore, ylelds a cured resin having a low heat distortion. Cpd. (2). is hexafunctional and 1tis reaction product is more rigid; since pert of the cross-linking will occur aliong the chain. Cpd. (3) is only tetrafunctional, but in this case the functions are located closely together on the very rigid aromatic nucleous. Cpd. (4) 1s quite similar to (3) but has an additional active hydrogen. Cpd. (5) has the very rigld aromatic "back-bone", plus an additional function, making a total of 6 active hydrogen atoms.

It is readily apparent that the heat distortion of the cured resin is directly dependent on the combination of three factors (a) the rigidity of the anine structure, (b) the number of functionally active hydrogen atoms, and (c). the distance between functional groups.

The curing of epoxide resins with the anhydrides presents a more complex reaction which has been elucldated with clarity only in the last few years. A number of competing renctions are possible, and it is believed that all. actually occur to a greater or lesser degree. In addition, it is observed that although certain catalytic effects do occur in the system, the anhydrides are truly reactivis hardeners which are chemleally bound as an integral part of the cured structure.

The anhydrides may be grouped into two matn classifications depending on the particular mechanisms involved in the curing process. The first group will cure epoxies through heat alone. The second group will require in addition, an alkaline promotor, usually a tertiary amine.

A characteristic anhydride which falls into the first, or non-promoted group, is phthalic anhydride. This anhydride requires extensive heat curing and produces a material which has been cross-linked through a combination of reactions. Slide 5 illustrates the three principle reactions which are believed to convert the fundamental resin into a highly cross-linked structure. In step (1), the anhydride reacts with a hydroxyl group to yield the reactive acid group. In step (2) the acid then condenses with the epoxide to yield the hydroxy-ester. It is here noted that a hydroxyl group has been regenerated, and thereby perinits the recurring reaction shown in step (1). Step (3) illustrates the random condensation which occurs between any epoxy with any hydroxyl group, to form the hydroxy-ether. It is again noted that hydroxyl groups are avallable for further reaction as in step (1).

The same reactions are shown in slide 6 , 1llustrating the build-up in molecular weight of the resinous intermediates. The anhydride (I) first reacts 
with the hydroxyl of the resin to form the half-ester (II). The newly forined.carboxylic acid group reacts with an epoxide from the adjacent chain to folw ain lutermediate low-polyner (III). Compound (II) can also condense through 1 ts epoxide group with the hydroxyl of the base resin, or the hydroxyl of any of the intermediate polyners to form Compound (IV). These interuediates have all of the functional groups required for continued condensation with additional anhydride and resin. The reaction thereby proceeds until cross-linking has been conpleted.

The promoted systems are based on those anhydrides which cannot cure epoxies alone. A tertiary amine is generally added, producing a selective reaction which is almost entirely one of esterification. Fquivalent proportions of. cnhydride and epoxy groups are employed, and the end product has properties simfliar to those of non-promoted systems. The promoted systems are belleved to be selective towards reactions (a) and (b) as 1llustrated on slide 6.

The acid anhydride cure generally produces better electrical and physical properties in the final specinen. However, the anhydrides are quite sensitive to moloture, and in addition, frequently difficult to dissolve. Anhydride-resin systems also require extensive curing at elevated temperatures in order to develop optimun properties. In view of their less complex handling characteristics, the anine-cured systems have come into extensive use as an acceptable compromise engendered by mass production requitrements.

In an earlier part of this discussion, an interesting relationship was noted between structure of hardener, and heat distortion of the fully cured resin. In addition, another correlation has been observed relating to volume resistivity. The volume resistivity 18 known to vary inversely with temperature at a rate characteristic of the given dielectric. With epoxy resins, the characteristic variations in resistivity are apparently due to the differences in the internal rigidities of the given structures. The data shows that for rigid, unmodified, epoxy systems, those resins, having the highest heat distortion also have the highest resistivities at elevated temperatures. Slide 7 outlines certain numerlcal data and curing information which affirm the above relationship.

It can be seen at once that each hardener produces a cured resin having a resistivity characteristic of that particular hardener. Although the amine and anhydride systems are grouped separately by virtue of their distinctive curing mechanisms and differences in internal structure, the pattern is st1ll common to each group, 1.e., the formulations having the highest heat distortion have the highest resistivities at elevated temperatures.

A great many facets of epoxy polvmer phenomena remain to be investigated and clarified by the many interested research groups. Indeed, much has already been accomplished, and it is particularly gratifying to learn that certain correlations may be made with expectations of success, purely on the basis of chemical configuration. 
<smiles>CC(C)SC1COC(CCl)C1</smiles><smiles>CC(C)(c1ccc(O)cc1)c1ccc(O)cc1</smiles>

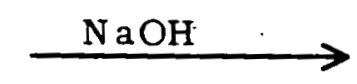

EPICHLOROHYDRIN - BISPHENOL "A"<smiles>CCCCOc1ccc(C(C)(C)c2ccc(OCC(O)COc3ccc(C(C)(C)c4ccc(OCC5CO5)cc4)cc3)cc2)cc1</smiles>

Slide 1 

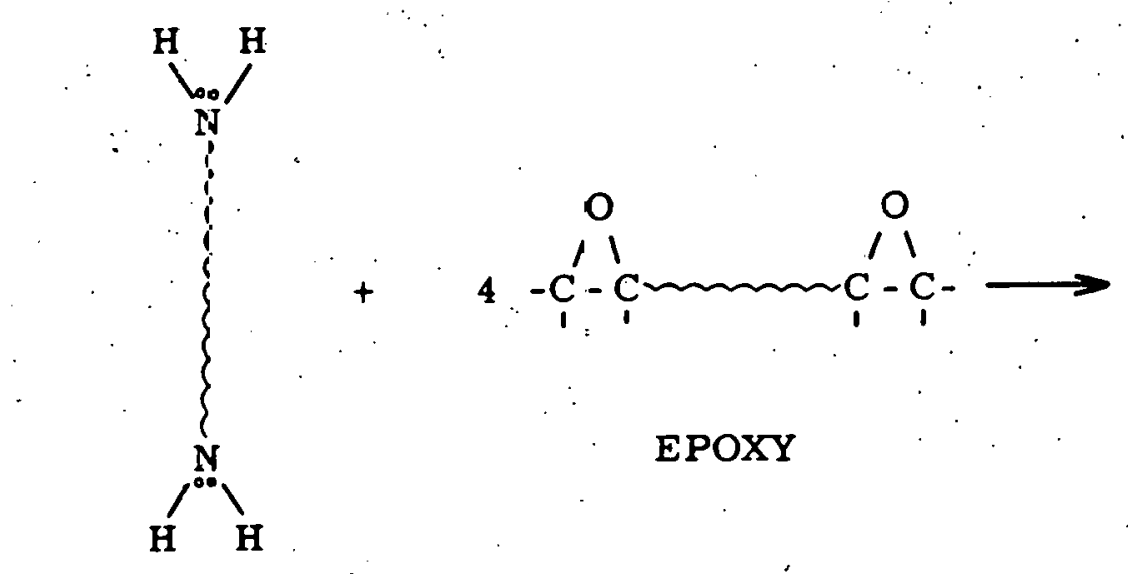

PRIMARY AMINE

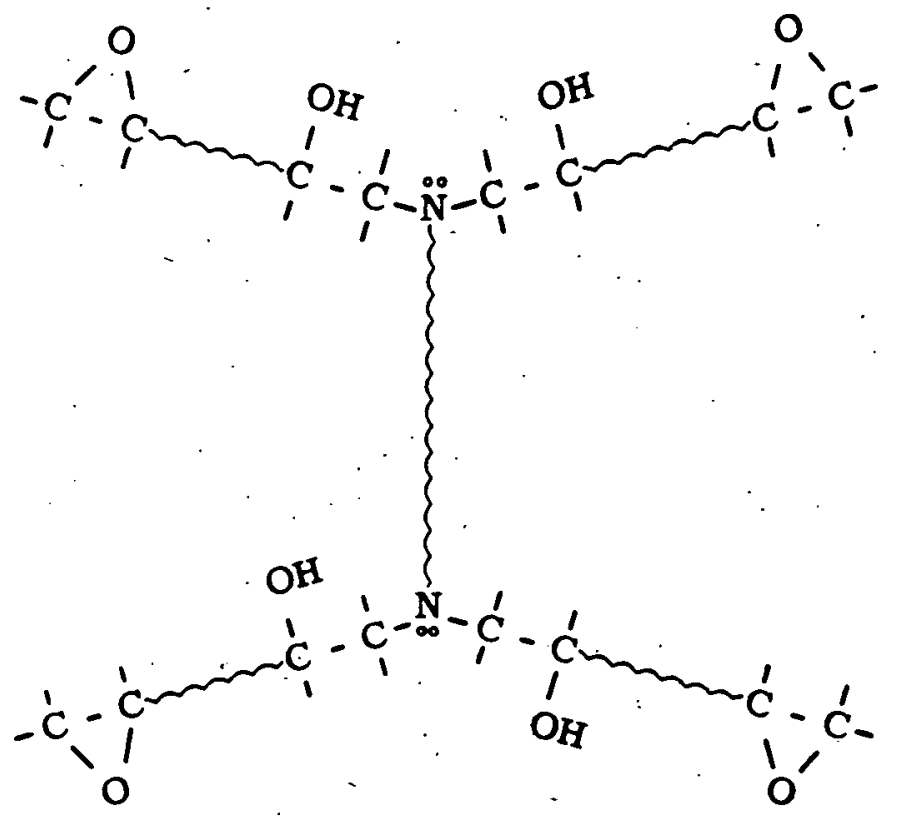

INTERMEDIATE POLYMER

Slide 2 

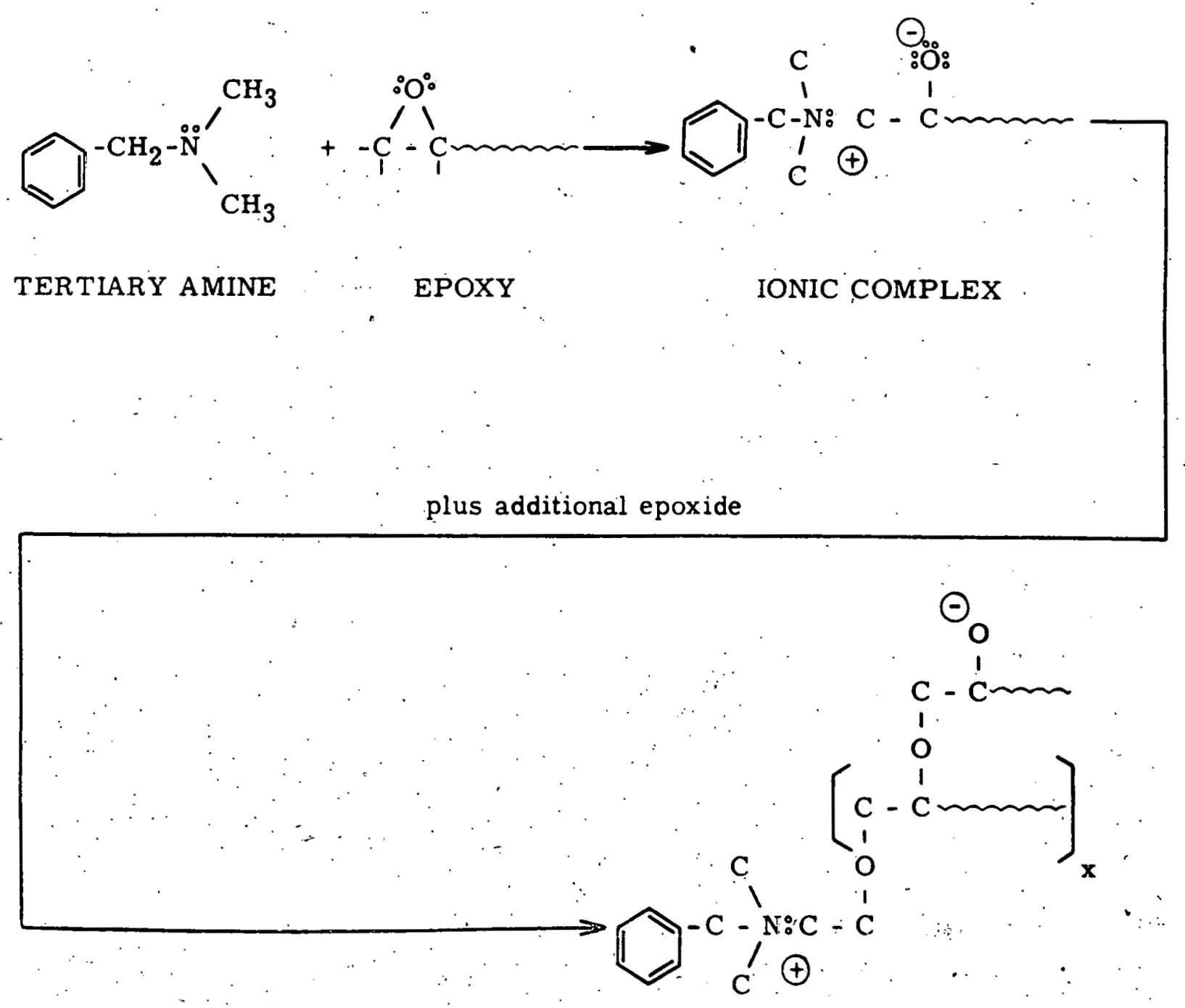

INTERMEDIATE IONIC COMPLEX 
(1) ethylenebisoxy propylamine<smiles>[NH2+]CCCOCCOCCCC=[NH2+]</smiles>

(2) triethylenetetramine

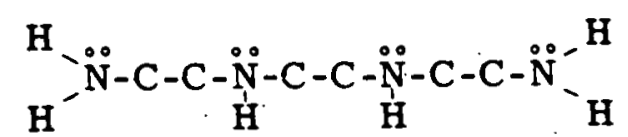

(3) m-phenylene diamine

(4) 2,4 diaminodiphenylamine
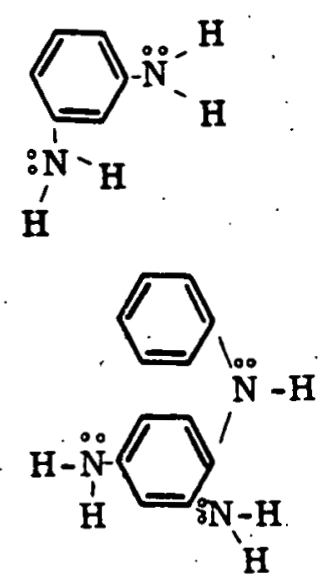

(5) trianilinomethane

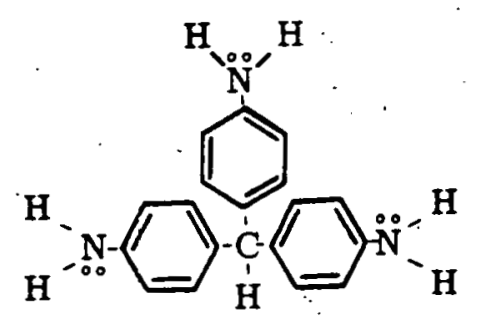


(1)
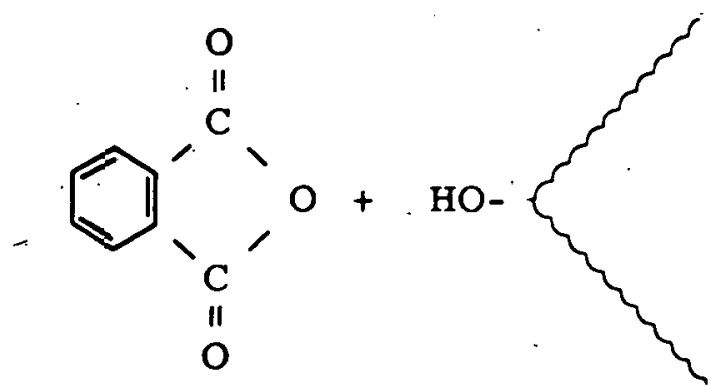

A.NHYDRIDE

$\mathrm{O}$
$-\stackrel{ }{\mathrm{C}}-\mathrm{OH}$

ACID

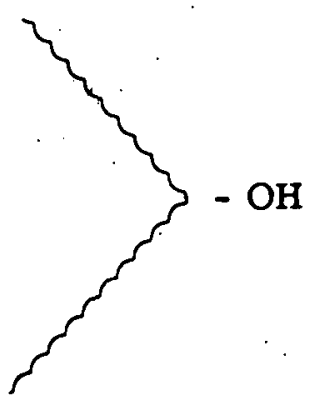

HYDROXYL
HYDROXYL

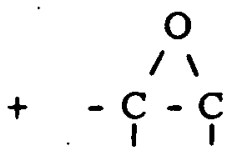

EPOXY

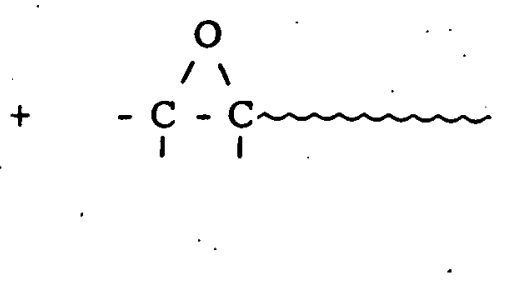

EPOXY

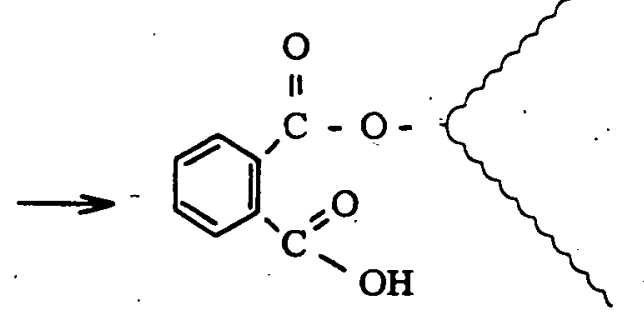

HALF-ESTER

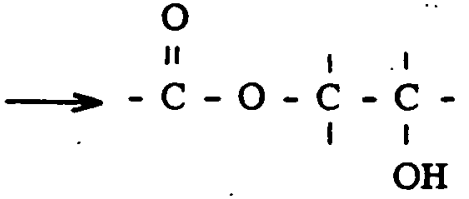

HYDROXY-ESTER

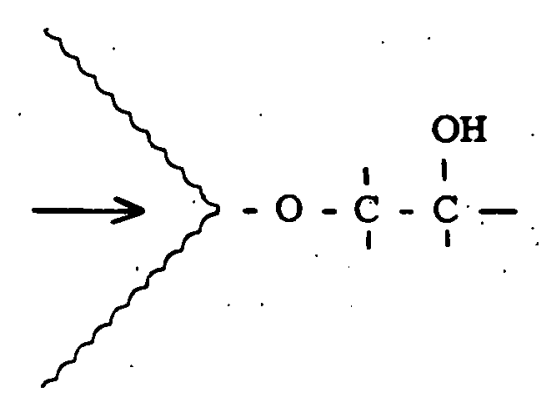

HYDROXY-ETHER 
(1)<smiles>O=C1CO[C@@H]2CO[C@H]1c1ccccc12</smiles>

ANHYDRIDE I BASE RESIN

(2)<smiles>O=C(O)c1ccccc1C(=O)OC(CCC1CO1)CC1CC1</smiles>

II

(3)

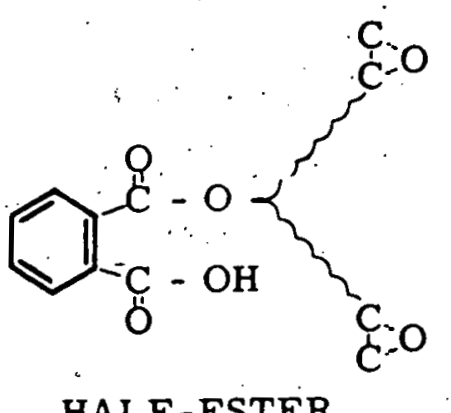

HALF - ESTER

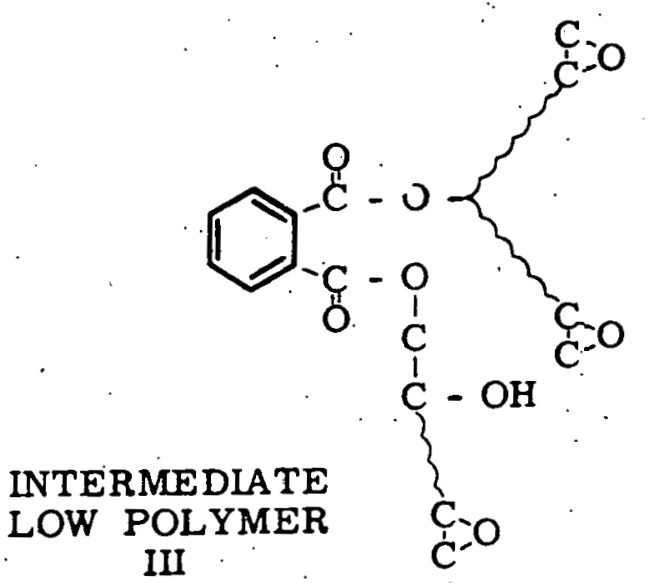<smiles>O=C(O)c1ccccc1C(=O)OC(CC1CC1)CC1CO1</smiles>

II<smiles>C1CC1CC1CO1</smiles>

ADDITIONAL RESIN<smiles>CC1CC1C(=O)C(O)C1CO1</smiles>

RESIN

Slide 6

INTERMEDIATE LOW POLYMER 


\begin{tabular}{|c|c|c|c|c|c|c|}
\hline \multicolumn{2}{|c|}{ HARDEINER } & 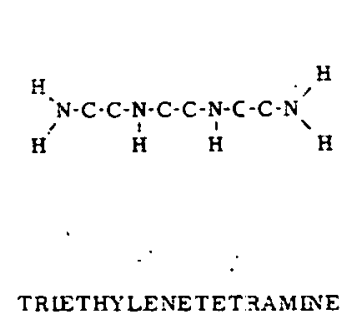 & O-PHENYLENE DLAM & TRLANILINOMETHANE & PETHALIC ANHY DRDE & \\
\hline \multicolumn{2}{|c|}{$\begin{array}{c}\text { PEACTVE } \\
\text { Pros? }\end{array}$} & $\begin{array}{l}1 \text { equivalent amino } \\
\text { hydrogen to } 1 \text { equivalent } \\
\text { epoxice (Epon } a ? E \text { ) }\end{array}$ & $\begin{array}{l}\text { 1) equivalent amino } \\
\text { hydrogen to } 1 \text { equjialent } \\
\text { epoxice (Evori } d 23 \text { ) }\end{array}$ & $\begin{array}{l}\text { 1. } 2 \text { equivalents amino } \\
\text { hydroges to } 1 \text { equivalemt } \\
\text { epoxide (Epon } 828)\end{array}$ & $\begin{array}{l}0.65 \text { equivalents anhydride } \\
\text { to } 1 \text { equivalent epoxide } \\
\text { (A.raldite sogen }\end{array}$ & 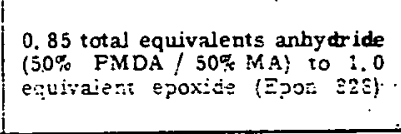 \\
\hline \multicolumn{2}{|l|}{ ClT:E } & $\frac{15 \text { r.ss. }}{\text { rm. temp. }}+\frac{15 \mathrm{hns}}{212^{\circ} \mathrm{i}}-\frac{4 \mathrm{hrs}}{300^{\circ} \mathrm{i}}$ & $\frac{15 \mathrm{hrs}}{212^{\circ} \mathrm{s}}+\frac{4 \mathrm{hrs}}{300^{\circ} \mathrm{f}}+\frac{2 \mathrm{hrs}}{400^{\circ} \mathrm{s}}$ & $\frac{i \mathrm{hrs}}{2120 !}+\frac{4 \mathrm{hrs}}{300^{\circ} \mathrm{i}}+\frac{2 \mathrm{hrs}}{4000 \mathrm{i}}$ & $\frac{15 \mathrm{hrs}}{300^{\circ} \mathrm{i}}+\frac{15 \mathrm{hrs}}{400^{\circ} \mathrm{s}}$ & $\frac{15 \mathrm{hrs}}{300^{\circ} \cdot \mathrm{i}}+\frac{15 \mathrm{brs}}{400^{\circ} i}$ \\
\hline \multicolumn{2}{|c|}{ 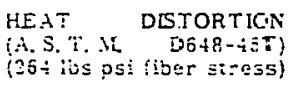 } & $220^{\circ} \cdot \mathrm{F}$ & $300^{\circ} \mathrm{F}$ & $390^{\circ}$ & $230^{\circ} \%$ & $420^{\circ} \mathrm{F}$ \\
\hline \multirow{5}{*}{$\begin{array}{c}\text { VOLUME } \\
\text { RESISTIVITY } \\
\text { (ohm-cm) }\end{array}$} & $100^{\circ} \mathrm{F}$ & $1.5 \times 10^{15}$ & $1.0 \times 10^{14}$ & $1.4 \times 10^{14}$ & $9.3 \times 10^{13}$ & $1 \times 10^{14}$ \\
\hline & $200^{\circ} \bar{F}$ & $8.1 \times 10^{12}$ & 8. $2 \times 10^{13}$ & $4.8 \times 10^{13}$ & $6.7 \times 10^{13}$ & $8.9 \times: 0^{13}$ \\
\hline & $300^{\circ}=$ & 4. $7 \times 10^{10}$ & $6.2 \times 10^{12}$ & $1.5 \times 10^{12}$ & $1.9 \times 10^{13}$ & $1.8 \times 10^{13}$ \\
\hline & $4000 \mathrm{r}$ & $. .5 \times 10^{3}$ & $4.8 \times 10^{9}$ & $3.6 \times 10^{10}$ & $23 \times 10^{11}$ & $2.7 \times 10^{11}$ \\
\hline & $500^{\circ} \mathrm{r}$ & * & * & $*$ & $3.7 \times: 0^{9}$ & $1.7 \times 10^{10}$ \\
\hline$\cdot$ & $600^{\circ}=$ & $\cdot$ & & & & $\cdots \quad 5.9 \times 10^{9}$ \\
\hline , & $550^{\circ} \mathrm{F}$ & 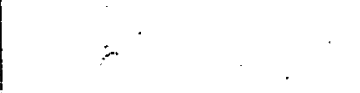 & - & . & • & * \\
\hline
\end{tabular}

* Erratic values indicate degredation at this cemperature 